\title{
The Contribution Rate of Higher Education on Economic Growth in the Central China, 2004-2013
}

\author{
Huadong Cheng ${ }^{1, a *}$, Kun Liü, b \\ ${ }^{1,2}$ Huazhong Agricultural University, No.1, Shizishan Street, \\ Hongshan District, Wuhan, Hubei Province, P.R.China \\ aemail: hdcheng@mail.hzau.edu.cn, bemail: charles.hzau@qq.com
}

Keyword: Higher education; Economic growth; Contribution rate; Central china

\begin{abstract}
Firstly, the contribution rate-estimating model was constructed by Cobb-Douglas production function. Secondly, the author estimated and analyzed the contribution rate of higher education on economic growth of whole country. especially, ShanXi, AnHui, JiangXi, HeNan, HuBei, HuNan province during the period of 2004-2013. The research showed that basic education was still played the prime role on the growth of economy; the potential contribution of higher education on the growth of economy didn't released totally; the phenomenon of scale and structural imbalance existed in the development of education in the central China. On the basis of these problems, the corresponding policy recommendations were proposed.
\end{abstract}

\section{Introduction}

Education can improve the comperhensive ability of workers and promote economic growth, but there still exist uncertainty and regional differences. The six provinces of central China including Shanxi, Anhui, Jiangxi, Henan, Hubei and Hunan provinces, there are many natural and cultural resources, sound foundation of science and education and regional advantages, which plays an important role on economic and social development in China. Due to the implementation of rising strategy in central region in 2006, the economic growth of the central China is obvious. In order to find out the main factors of economic development of the central China in last ten years, it is necessary to measure and analyze the contribution rate of higher education on economic growth, which is very important for the reform and development of higher education in the central china.

From 1950s, economists devoted to explain what increased the economic growth, and education was interpreted as "missing" to promote the source of output growth, or the "residual term" of technological change. Denison (E.F. Denison) used the input growth index to explain that the US national income increased 3.87\% between 1948 and 1973, in which the labor education explained $11 \%{ }^{[1]}$. Bauman (M.J. Bowman) studied the contribution of education on economic growth of 22 countries between 1950 and 1962, and found that only four countries whose the contribution rate of education over $10 \%{ }^{[2]}$. We estimated highly the contribution of education, Sa Carlo Pross (G. Psacharopoulos) surveyed 29 countries, also found that the direct effect of education on average only explain the total growth of $8.7 \%{ }^{[3]}$. This data may be underestimated in developing countries , based on largely shortage of technical workers in these countries. Therefore, the domestic scholars also estimated the contribution rate of education to economic growth. On one hand, measured the different periods in the whole country, like Cui Yuping used Denison and Madison's algorithm calculated the contribution rate of higher education on economic growth rate of 1982-1990 ${ }^{[4]}$. Song Huaming and Wang Rong estimated the contribution rate of higher education on economic growth in China during 1990-1999 ${ }^{[5]}$. Hang Yongbao calculated the contribution rate of primary school, secondary school, high school, secondary vocational, higher vocational, undergraduate education on economic growth of 1993-2004 ${ }^{[6]}$. Chen Junsheng calculated the contribution rate of the higher education on economic growth of china during the period of 1996-2005, find out the higher education contribute $2.65 \%$ on economic growth ${ }^{[7]}$. On the other hand, measured different province. Liu Lin, Cui Yuping ${ }^{[8]}$ calculated the contribution rate of higher education on economic growth in 
Jiangsu province during the period of 1996-2005. The contribution rate of higher education on economic growth between 1996 and 2005 in Beijing was estimated by Cheng Lanfang and Wang Yuanyuan $^{[9]}$. As far as the existing research was concerned, firstly, the time span of the existing research lack of continuity, and there was a broken period in the last ten years. secondly, the studies focus on the range of the whole country or single province, and lack of the meso perspective study. Based on these, the author adopted Cobb-Douglas production function model estimated and compared the contribution rate of central territory, 2004-2013. In order to provide a reference for the next five years of the development of the central region of higher education.

\section{Model selection of the contribution on economic growth of education}

The C-D production function referred to Cobb Douglas production function, widely used in economics. It was published by American mathematician Cob and economist Douglas, when theye studied the relationship between input and output of the manufacturing sector in the US. When the technical and economic conditions are certain, the relationship between output and input of labor and capital can be expressed as:

$$
Y=A K^{\alpha} L^{\beta}
$$

In the upper, $Y$ represents output, A represents the technological level constant, $K$ represents the amount of capital invested, and $L$ represents the amount of labor invested, the output elasticity of $L$ and $\mathrm{K}$ are respectively represented by the $\alpha$ and $\beta, \alpha>0, \beta>0, \alpha+\beta=1$.

Among the many factors of economic growth, human resources were basic factor. In the theory of human capital, it pointed out that education can improve the skill and ability of workers and promote the development of economy. which is equivalent to increase the amount of the initial investment. Therefore, the $\mathrm{L}$ can be decomposed into the product of the initial labor $\mathrm{L}_{0}$ and the education investment $\mathrm{E}$, so, the production function can be changed to:

$$
Y=A_{t} K_{t}^{\alpha}\left(L_{0 t} E_{t}\right)^{\beta} \quad(\mathrm{t} \text { is time variable })
$$

Seeking the natural logarithm of $t$, and the differential equation was replaced by using the poor differential equation:

$$
\mathrm{y}=C+\alpha K+\beta L_{0}+\beta E
$$

Among them, y represents the average annual economic growth rate of a certain period of time, $\mathrm{C}$ represents the technological advances, $\mathrm{K}$ represents the average annual growth rate of capital investment, $\mathrm{L}_{0}$ represents the initial annual growth rate of labor, E represents the annual growth rate of investment in education. Therefore, the contribution of education on economic growth can be expressed by the following formula:

$$
R_{e}=\frac{\beta E}{Y}
$$

In the practical calculation, the average annual growth rate of $E_{c}$ was used to replace the annual growth rate of $\mathrm{E}$. because the education comprehensive index reflects the level of education of the labor force in a certain country or region. It was based on a certain level of education as a benchmark, in accordance with a certain labor rate (or labor conversion factor, such as wages, productivity, education years) translation per capita education level, reflect the actual effect of educational investment ${ }^{[10]}$. So, the ultimate formula for the contribution of education on economic growth is:

$$
R_{e}=\frac{\beta E_{c}}{Y}
$$

Among them, labor input and output coefficient $\beta$ varies from different periods and regions. Generally, the value of $\beta$ was taked $0.7-0.8$, Madison's estimated value was $0.7^{[11]}$, Denison value was $0.73^{[12]}$. In this study, Denison's value was applied. 
The contribution of education on economic growth in the middle-provinces

The distribution of educational level of employment personnels in the middle-provinces

According to China Labor Statistics Yearbook 2005 and China Labor Statistical Yearbook 2014, the data about the distribution of the educational level of the employment personnels were sorted into table 1 and table 2.

Table 1: the distribution of the education level of employment personnels ,2004

$(\%)$

\begin{tabular}{cccccc}
\hline Region & Llliteracy & $\begin{array}{c}\text { Primary } \\
\text { school }\end{array}$ & $\begin{array}{c}\text { Junior high } \\
\text { school }\end{array}$ & $\begin{array}{c}\text { Senior high } \\
\text { school }\end{array}$ & $\begin{array}{c}\text { College degree or } \\
\text { above }\end{array}$ \\
\hline whole country & 6.2 & 27.4 & 45.8 & 13.4 & 7.23 \\
Shanxi & 1.7 & 19.3 & 59.6 & 12.4 & 6.98 \\
Anhui & 10.2 & 28.6 & 45.4 & 10.0 & 5.78 \\
Jiangxi & 4.2 & 31.5 & 43.7 & 14.3 & 6.15 \\
Henan & 4.1 & 21.8 & 55.2 & 13.1 & 5.85 \\
Hubei & 7.5 & 27.4 & 43.8 & 15.5 & 5.88 \\
Hunan & 3.7 & 30.1 & 46.1 & 13.4 & 6.65 \\
\hline
\end{tabular}

Table 2: the distribution of the education level of employment personnels, 2013

$(\%)$

\begin{tabular}{cccccc}
\hline Region & Llliteracy & $\begin{array}{c}\text { Primary } \\
\text { school }\end{array}$ & $\begin{array}{c}\text { Junior high } \\
\text { school }\end{array}$ & $\begin{array}{c}\text { Senior high } \\
\text { school }\end{array}$ & $\begin{array}{c}\text { College degree or } \\
\text { above }\end{array}$ \\
\hline whole country & 1.9 & 18.5 & 47.9 & 17.1 & 14.60 \\
Shanxi & 0.8 & 10.4 & 53.2 & 20.3 & 15.29 \\
Anhui & 5.7 & 22.8 & 50.0 & 11.4 & 10.14 \\
Jiangxi & 1.3 & 18.6 & 50.9 & 18.5 & 10.76 \\
Henan & 1.9 & 15.6 & 54.5 & 17.7 & 10.22 \\
Hubei & 1.7 & 16.4 & 48.1 & 20.4 & 13.49 \\
Hunan & 0.8 & 15.0 & 45.5 & 23.8 & 14.80 \\
\hline
\end{tabular}

From table 1 shows that in 2004, the employment personnels who got the middle school education account for $45.8 \%$ in whole country, in the middle-provinces, Shanxi Province, the highest, account for 59.6\%; Henan Province, 55.2\%, rank the second, the remained, Hunan, 46.1\%, Anhui, 45.4\%, Hubei, 43.8\%, and Jiangxi, 43.7\%. Shanxi, Henan and Hunan provinces above the nationwide level. From the perspective of higher education, the national level was $7.23 \%$, and the middle-provinces were lower than nation, which means that the development of higher education in the middle-provinces was still backward the whole country. the top three provinces whose higher education level of employment personnels were: Shanxi 6.98\%, Hunan 6.65\%, Hubei 5.88\%.

From table 2 shows that in 2013, the employment personnels in the middle-provinces and whole country mainly received the junior high school education. However, the proportion of those who got higher education increased significantly. The rate of the whole country was $14.60 \%$ in 2013 , two times than 2004, which means that the higher education in china was developing rapidly in the last ten years. In the middle-provinces, only Shanxi and Hubei province were higher than the whole country, another four provinces were lower, which showed that the development of higher education in the middle-provinces was not balanced.

\section{The per capita education years of the employment personnel in the middle-provinces}

In order to calculate the education years of all levels for the national employment personnels in 2004, for example, as follows:

Per capita education years of Primary school: $(27.4+45.8+13.4+7.23) \times 6 \div 100=5.63$ 
Per capita education years of Junior school: $(45.8+13.4+7.23) \times 3 \div 100=1.99$

Per capita education years of Senior school:(13.4+7.23) $\times 3 \div 100=0.62$

Per capita education years of College degree or above: $7.23 \times 4 \div 100=0.29$

In the same way, we were calculated the education years of the middle-provinces during the period of 2004-2013.

Table 3:employment personnels in the middle-provinces of Education years in 2004

\begin{tabular}{ccccc}
\hline Region & $\begin{array}{c}\text { Per capita education years } \\
\text { of primary school }\end{array}$ & $\begin{array}{c}\text { Per capita education } \\
\text { years of junior school }\end{array}$ & $\begin{array}{c}\text { Per capita } \\
\text { education years of } \\
\text { senior school }\end{array}$ & $\begin{array}{c}\text { Per capita education } \\
\text { yef college degree } \\
\text { or above }\end{array}$ \\
\hline whole country & 5.63 & 1.99 & 0.62 & 0.29 \\
Shanxi & 5.90 & 2.37 & 0.58 & 0.28 \\
Anhui & 5.39 & 1.84 & 0.47 & 0.23 \\
Jiangxi & 5.74 & 1.92 & 0.61 & 0.25 \\
Henan & 5.76 & 2.22 & 0.57 & 0.23 \\
Hubei & 5.55 & 1.96 & 0.64 & 0.24 \\
Hunan & 5.78 & 1.98 & 0.60 & 0.27 \\
\hline
\end{tabular}

In the whole country and the middle-provinces, the education years of the employment personnels were mainly based on the primary school. in 2004, per capita primary education years of the whole country reached 5.63 years. In the middle-provinces, only Anhui and Hubei provinces were lower than the whole country, which shows that the primary education level in the central region was relatively higher. from the perspective of per capita education years of higher education, the middle-provinces were lower than the whole country too. The top three provinces were Shanxi, Hunan and Jiangxi provinces.

Table 4: employment personnels in the middle-provinces of the education years in 2013 (year)

\begin{tabular}{ccccc}
\hline Region & $\begin{array}{c}\text { Per capita education } \\
\text { years of primary school }\end{array}$ & $\begin{array}{c}\text { Percapita education } \\
\text { years of junior } \\
\text { school }\end{array}$ & $\begin{array}{c}\text { Per capita education Per capita education years } \\
\text { years of senior } \\
\text { school }\end{array}$ & $\begin{array}{c}\text { of college degree or } \\
\text { above }\end{array}$ \\
\hline whole country & 5.89 & 2.39 & 0.95 & 0.58 \\
Shanxi & 5.95 & 2.66 & 1.07 & 0.61 \\
Anhui & 5.66 & 2.15 & 0.65 & 0.41 \\
Jiangxi & 5.92 & 2.41 & 0.88 & 0.43 \\
Henan & 5.88 & 2.47 & 0.84 & 0.41 \\
Hubei & 5.90 & 2.46 & 1.02 & 0.54 \\
Hunan & 5.95 & 2.52 & 1.16 & 0.59 \\
\hline
\end{tabular}

In 2013, the middle-provinces employment personnels whose education years were still in primary school, nationwide employment personnels per capita primary education year were 5.89 years, it increased by $4.54 \%$ compared to 2004 , the rate of the growth was small. Per capita years of higher education of the employment personnels increase rapidly, the whole country increased $53.57 \%$, Shanxi province increased $83.57 \%$, Hunan province increased $92.73 \%$, and Hubei province increased $58.39 \%$, the growth rate of the per capita education years of the higher education was the largest. From 2004 to 2013, the whole country increased 129.34\%, Hubei Province, increased 122.57\%, Hunan Province, increased 119.08\%, Shanxi Province, increased $101.90 \%$, the growth rate of these three provinces were higher than the whole country. It shows that the development of higher education in these three provinces were higher in recent ten years, and the scale of higher education was significantly expanded. However, the growth rate of employment personnels who has accepted higher education was about $75 \%$. In Anhui, Jiangxi and Henan province, obviously lower than the whole country, and its development was relatively slow. So, the development of higher 
education of the middle-provinces was imbalanced.

\section{The education comprehensive index and its average annual growth rate of the employed persons in the middle-provinces, 2004-2013}

It is need to determine the labor simplification rate before calculate the education comprehensive index. Marx believes that calculate the productivity of complex labor can be convert to a certain quantities of simple labor, through the labor to simplify the coefficient, the complex labor quantity was simplied to simple labor quantity ${ }^{[13]}$.

In this study, we were utilized Li Hongtian's study (2001) and calculated the education comprehensive index. He pointed out thant primary school, junior high school, senior high school and the University's labor simplify rate were $1,1.2,1.4$ and $2^{[14]}$.

In 2004, the education comprehensive index of employment personnels for whole country was calculated as follows:

$$
5.63 \times 1+1.99 \times 1.2+0.62 \times 1.4+0.29 \times 2=9.47
$$

Similarly, the education comprehensive index of employment personnels for whole country was 11.25 in 2013.

Therefore, from 2004 to 2013, the average annual growth rate of the education composite index was:

$$
E_{C_{2004-2013}}=\left[(11.25 \div 9.47)^{1 / 9}-1\right] \times 100 \%=1.93 \%
$$

After eliminated the higher education factor, the average annual growth rate of the education comprehensive index was:

$$
\left\{\{[11.25-(2 \times 0.58)] \div[9.47-(2 \times 0.29)]\}^{1 / 9}-1\right\} \times 100 \%=1.41 \%
$$

So, the contribution rate of higher education on nationwide education comprehensive index average annual growth rate was:

$$
E_{h c_{2004-2013}}=\frac{1.93 \%-1.41 \%}{1.93 \%} \times 100 \%=26.91 \%
$$

At the same time, in the last ten years, the contribution rate of basic education on nationwide education comprehensive index average annual growth rate was:

$$
1-26.91 \%=73.09 \%
$$

In the same way, the index of the employment personnels for the middle-provinces can be obtained respectively (Table 5).

Table 5:the average annual growth rate of the education comprehensive index

$(\%)$

\begin{tabular}{cccccc} 
Region & $\begin{array}{c}\text { Education } \\
\text { composite } \\
\text { index of 2004 }\end{array}$ & $\begin{array}{c}\text { Education } \\
\text { composite index } \\
\text { of 2013 }\end{array}$ & $\begin{array}{c}\text { The average annual } \\
\text { growth rate of } \\
\text { education composite } \\
\text { index }\end{array}$ & $\begin{array}{c}\text { Contribution } \\
\text { rate of Higher } \\
\text { Education }\end{array}$ & $\begin{array}{c}\text { Contribution rate of } \\
\text { Basic Education }\end{array}$ \\
\hline whole country & 9.47 & 11.25 & 1.93 & 26.91 & 73.09 \\
Shanxi & 10.11 & 11.86 & 1.79 & 32.80 & 67.20 \\
Anhui & 8.71 & 9.95 & 1.49 & 23.06 & 76.94 \\
Jiangxi & 9.40 & 10.90 & 1.66 & 19.39 & 80.61 \\
Henan & 9.69 & 10.84 & 1.25 & 25.88 & 74.12 \\
Hubei & 9.27 & 11.35 & 2.27 & 23.82 & 76.18 \\
Hunan & 9.53 & 11.79 & 2.39 & 22.95 & 77.05 \\
\hline
\end{tabular}




\section{The actual average annual growth rate of GDP in the central provinces of 2004-2013}

According to China Statistical Yearbook 2014, Shanxi statistical yearbook 2014, Anhui statistical yearbook 2014, Jiangxi statistical yearbook 2014, Henan statistical yearbook 2014, Hubei statistical yearbook 2014 and Hunan statistical yearbook 2014 , and the actual annual growth rate of GDP were calculated.

For instance:

$$
Y_{2004-2013}=\left[(2608.6 \div 1087.4)^{1 / 9}-1\right] \times 100 \%=10.21 \%
$$

Similarly, can be calculated in the middle-provinces. Due to the statistical yearbook of different provinces in the calculation of GDP index base year were not the same, the value between different provinces of the same year have a big difference (Table 6). Actually, in practical computation process only needs real GDP average annual growth rate, that's means has no effect on the results.

Table 6: GDP index and the actual average annual growth rate in the middle-provinces

\begin{tabular}{|c|c|c|c|}
\hline Region & GDP Index of 2004 & GDP Index of 2013 & $\begin{array}{c}\text { The actual average annual growth } \\
\text { rate of GDP }(\%)\end{array}$ \\
\hline whole country ${ }^{*}$ & 1087.4 & 2608.6 & 10.21 \\
\hline Sahnxi ${ }^{* *}$ & 5416.1 & 14182.7 & 11.29 \\
\hline Anhui * & 1241.65 & 3624.3 & 12.64 \\
\hline Jiangxi ${ }^{*}$ & 1111.5 & 3198.5 & 12.46 \\
\hline Henan ${ }^{* *}$ & 4416.2 & 12428.8 & 12.18 \\
\hline Hubei $^{* *}$ & 4802.5 & 14394.4 & 12.97 \\
\hline Hunan * & 931.7 & 2782.0 & 12.92 \\
\hline
\end{tabular}

Note: * represents its index of GDP in 1978 as the base year, namely 1978=100;* *represents its index of GDP in 1952 as the base year, namely $1952=100$; The total value of the product in the table is calculated by the same price (comparable price).

In 2004-2013, The actual average annual growth rate of GDP was in a high level in the middle-provinces. Among them, the middle-provinces were higher than nationwide level. in addition to, except the Shanxi Province, the GDP real annual growth rate more than $12 \%$. This indicates that, since 2006, the central rising strategy implementation has a positive effect on the economic and social development.

\section{The contribution of education to the actual average annual growth rate of GDP}

Using the formula (5) to calculate the contribution of education on the nationwide average annual growth rate of GDP, as follows:

$$
R_{e}=\frac{\beta E_{c_{2004-2013}}}{Y_{2004-2013}}=\frac{0.73 \times 1.93 \%}{10.21 \%} \times 100 \%=13.81 \%
$$

Then, the contribution of higher education to the actual annual growth rate of GDP was:

$$
R_{h e}=E_{h c_{2004-2013}} \times R_{e}=26.91 \% \times 13.81 \%=3.72 \%
$$

At the same time, the contribution of basic education to the actual annual growth rate of GDP was:

$$
73.09 \% \times 13.81 \%=10.10 \%
$$

In the same way, obtained the contribution rate to the actual annual growth rate of GDP in the middle-provinces, and calculated the average level of middle-provinces (Table 7). In order to further compare the difference between basic education and higher education on economic growth, the two were subtracted (Table 8). 
Table 7: the contribution of education to the actual average annual growth rate of GDP

$(\%)$

\begin{tabular}{cccc}
\hline Region & Contribution rate of Education & $\begin{array}{c}\text { Contribution rate of Higher } \\
\text { Education }\end{array}$ & $\begin{array}{c}\text { Contribution rate of Basic } \\
\text { Education }\end{array}$ \\
\hline whole country & 13.81 & 3.72 & 10.10 \\
Shanxi & 11.57 & 3.80 & 7.78 \\
Anhui & 8.60 & 1.98 & 6.62 \\
Jiangxi & 9.72 & 1.88 & 7.83 \\
Henan & 7.51 & 1.94 & 5.57 \\
Hubei & 12.80 & 3.05 & 9.75 \\
Hunan & 13.52 & 3.10 & 10.41 \\
Average level of & 10.62 & 2.63 & 7.99 \\
Central region & & &
\end{tabular}

Table 8: the difference between basic education and higher education on economic growth contribution rate

\begin{tabular}{ccccccccc}
\hline Region & $\begin{array}{c}\text { whole } \\
\text { country }\end{array}$ & Shanxi & Anhui & Jiangxi & Henan & Hubei & Hunan & $\begin{array}{c}\text { Average level of } \\
\text { Central region }\end{array}$ \\
\hline $\mathrm{a}^{*}-\mathrm{b}^{* *}$ & 6.38 & 3.98 & 4.46 & 5.95 & 3.63 & 6.7 & 7.31 & 5.36
\end{tabular}

Note: * represents the basic education on economic growth contribution rate; ${ }^{* *}$ represents the higher education on economic growth contribution rate.

\section{Conclusions and recommendations}

The contribution of basic education on economic growth was still occupied the main position. In the last ten years, the contribution rate of basic education on economic growth of whole country, Shanxi, Anhui, Jiangxi, Henan, Hubei and Hunan provinces were $10.10 \%, 7.78 \%, 6.62 \%, 5.57 \%$, $9.75 \%, 10.41 \%$ and $7.83 \%$ respectively. The contribution rate of higher education on economic growth were $3.72 \%, 3.80 \%, 1.88 \%, 1.94 \%, 1.98 \%, 3.05 \%$ and $3.10 \%$ respectively. Whether from the nationwide or middle-provinces perspective, the former was far higher than the latter. Basic education was still occupied the main position in the current economic and social development. Therefore, at this stage, china should further strengthen the investment in basic education, optimize the allocation of resources, improve the quality of basic education, and play a good role in the economic growth.

\section{The potential of contribution of higher education on economic growth has not been fully} released.

The contribution rate of higher education on the nationwide GDP growth was $2.65 \%$ in 1996-2005. While, it was $3.72 \%$ in 2004-2013, compared to the previous ten years, an increase of 1.07 percentage points. However, the gross enrollment rate of higher education in China increased from $19 \%{ }^{[15]}$ to $34.5 \%{ }^{[16]}$. Increased by 15.5 percentage points. Although, the proportion of employment personnels who acceptted higher education were greatly increased, the contribution rate of higher education on economic growth has not increased significantly. At the same time, there was big gap compared with international countries. Becker,E Willian ${ }^{[17]}$ (1993) has been researched the contribution rate of higher education on GDP growth in the US, Britain, Japan, Germany, France, Holland, during the period of 1973-1984, and pointed out that their contribution rate were $14.61 \%$, $8.64 \%, 4.20 \%, 2.48 \%, 10.52 \%, 5.90 \%$ respectively. Obviously, the contribution rate of higher education on economic growth was far from playing. What's the reasons lead to the phenomenon? Firstly, the duration of employment personnels who acceptted higher education was too short. By the end of 2013, its duration was only 0.58 years, was still less than 1 years; Secondly, due to 
technological progress, resulting in the reduction of employment personnels opportunities, Which produced bad influence on the contribution of education to economic growth. Peng Xushu (2002) ${ }^{[18]}$ has conducted an empirical study on the relationship between technological progress and employment in the United States during the period of 1947-1998, and pointed out that there was a negative correlation between technological progress and the marginal employment elasticity of economic growth, technological progress has a strong labor substitution characteristics. Marx also pointed out that with the development of the large-scale industry, the creation of real wealth was less dependent on the labor time and the amount of labor, but more depends on the general level of science and technological progress, or that depends on the use of science in production ${ }^{[19]}$. Obviously, in the last ten years, china has made great progress on the science and technology. Therefor, the reduction of employment opportunities was inevitable. It is easy to understand the issue of College Students' employment in recent years. Thirdly, the industrial structure needs to be optimized. At present, China's economic growth is still depend on labor-intensive industries, rather than the technical and intensive industries, resulting in the supply of human capital and the demand side of the asymmetry, and produced the phenomenon of structural unemployment.

Thus, china should further increase the chances of employment personnels receiving higher education. At the same time, the objective view of the relationship between technological progress and employment, and actively change the way of economic development, optimize the industrial structure, give full play to the role of higher education talents, and eliminate the phenomenon of structural unemployment.

\section{The imbalance of the scale and structure of the education development in the middle-provinces}

A comparison of the whole country and the middle-provinces, the average annual growth rate of GDP in the middle-provinces during 2004-2013 was $12.41 \%$, it was 2.20 percentage points higher than the nationwide level. Among them, the contribution rate of basic education on economic growth was $7.99 \%$, and lower than the national level of 2.02 percentage points. Higher education on its contribution rate of $2.63 \%$, and lower than the nationwide level of 1.09 percentage points. Although, the rapid economic growth of the middle-provinces in the last ten years, the contribution rate of the basic education and higher education on the economic growth was still in a low state, compared with the nationwide level. The foundational education particularly. From the internal comparison of middle-provinces, in the last ten years, the actual average annual growth rate of GDP : Hubei, 12.97\%, Hunan, 12.92\%, Anhui, 12.64\%, rank the first three places. The contribution rate of higher education on the actual average annual growth rate of GDP: Shanxi, 3.80\%, Hunan, $3.10 \%$, and Hubei province, 3.05\%, rank the first three places. The contribution rate of basic education on the actual average annual growth rate of GDP: Hunan, Hubei, Jiangxi rank the first three places, there were $10.41 \%, 9.75 \%, 7.83 \%$ Respectively. In Anhui, Jiangxi, Henan province, the contribution of higher education on the economic growth was still at a lower level, not only lower than the nationwide level but also backward the other provinces. In terms of basic education, the performance of Jiangxi province was best, Anhui and Henan two provinces were still lower than the nationwide level and the average level of the middle-provinces. It's means that the contribution of education on the economic growth emerged a "local collapse" phenomenon in the central region.

Therefore, china should continue to increase investment of education in the central region, especially, basic education. meanwhile, continuing the implementation of rising strategy in central region, optimizing the investment structure of higher education, promoting the structural symmetry bewteen the educational investment and educational layout, play a multiplier effect of higher education in the central region, and improve the contribution rate of education on economic growth. In addition, the development of education should according the principle of adaptation to local conditions. Different provinces in the education development plan should pay attention to the structural adjustment and balance, and promote the effective contribution of education development on economic development. Also, should avoid the negative effect of the "spillover effect" of the talents. Take Hubei province as an example, because of the "spillover effect", the contribution rate 
of higher education on economic growth was lower. Most of the talents loss to the eastern region, weaken the contribution to regional economic growth. Thus, we should strengthen the active interaction in education and regional economic, and absorb the outstanding human resources into effective productivity.

\section{References}

[1] Denison E.F. Accounting for slower growth: An update. In: Kendrick J.W.(ed.) International Comparisons of Productivity and Causes of the Slowdown. Ballinger, Cambridge, Massachusetts. 1984: 5.

[2] Bowman M.J. Education and economic growth: An overview. In: King T.(ed.) Education and Income: A Background Study for World Development Report. World Bank Staff Working Paper No.402. World Bank, Washington, DC.1980.

[3] Psacharopoulos G. Returns to education: A further international update and implications. J.Hum. Resources.20(4), 583-604(1985).

[4] Yuping Cui .Journal of Beijing Normal University (Humanity and Social Sciences Education), 01, 31-37(2000). (In Chinese)

[5] Huaming Song, Rong Wang. The Higher Engineering Education Research, 01, 55-58(2005). (In Chinese)

[6] Yongbao Hang. Education Research, 02, 38-47(2007). (In Chinese)

[7] PingZhou, Junsheng Chen, Xiaoyan Xu. Heilong Jiang High Education Research, 12, 49-50 (2007). (In Chinese)

[8] Yuping Cui, Lin Liu, Zengji Du. Practice and Cognition of Mathematics, 03:54-62(2009). (In Chinese)

[9] Lanfang Cheng, Yuanyuan Wang. Liaoning Education Research, 09, 12-14(2008). (In Chinese)

[10] Yajun Yang, Hongtian Li. Education Research, 07, 90-93(2006).(In Chinese)

[11] Maddison, A.Growth and slow down in advanced capitalist economies: Journal of Economic Literature, (2), 649-698(1987).

[12] Denison E F. New York: Committee for Economic Development, 1962.

[13] Yongjie Lang, Wenqing Wu, cattle Fenggao, Ding Wang.Theory and Practice of Education, 16, 61-64(2011). (In Chinese)

[14] Hongtian Li.Journal of Nanjing Political College, 06, 100-104(2001).(In Chinese)

[15] Information on http://www.moe.edu.cn

[16] Information on http://www.moe.edu.cn

[17] Becker,Willian E.\& Lewis, Darrell R(Eds.), Higher Education and Economic Growth, Norwell, USA: Kluw-er Academic Publishers, 1993. pp. 56- 57.

[18] Xushu Peng, Guo Qi. Number of Economic and Technological Economic Research, 11, 36-40(2002). (In Chinese)

[19] Marx, Engels. Complete works of Marx and Engels. Beijing, 1980. (In Chinese) 